\title{
Teaching English as a Second Language: The Role of Noticing the Gap
}

\author{
Alexandra Uzoaku Esimaje \\ Faculty of Arts and Education, Benson Idahosa University, Benin City, Edo state, Nigeria \\ Email: alexandra.esimaje@live.com
}

\begin{abstract}
The role of consciousness in learning has dominated current debate on second language learning. This is now the focal point of recent research by philosophers, psychologists, language theorists, linguists and especially language teachers who carry the burden of pedagogical consequences. The singular question is how can successful language learning be achieved? In this paper, attempt at answer is made through the appraisal of the effect of consciousness, awareness or noticing on learning. It is argued that an effective way of learning is to raise the awareness of a learner on a language item to cause him to notice it and subsequently learn or internalize its use. A number of factors influence noticing but this paper focuses on the gap between the observed input and the learners typical output. The aim is to provide remedy to performance errors via positive feedback. In the paper, 'learner' is used to refer to every second language user but immediate attention is paid to the teacher at the intermediate level of education. The aim of the study is to enhance the communicative ability of the teacher by highlighting his performance errors, raising his awareness of them through the concept of noticing and subsequently providing him with positive feedback. Ultimately, the study hopes to invigorate the teacher towards self development and thus position him to effectively create linguistic appetite in other learners rather than linguistic apathy. The study used selected secondary school teachers in Maiduguri and Benin, as case study. The study submits that noticing, raising the consciousness of learners on what is right or wrong usage is a useful way to enhance the learning of English as a second language in our schools in Nigeria.
\end{abstract}

Index Terms - second language learning, performance errors, noticing, gap, learning consciousness, successful learning, English and Nigeria

\section{INTRODUCTION}

\section{A. The Concept of Noticing}

The concept of noticing is an innovation in language teaching which is a major step in the implementation of Lewis' $(1993,1997)$ Lexical Approach. Speaking on the major contribution of the Lexical Approach to linguistic theory, Lewis (1997, p. 7) says;

The most fundamental linguistic insight of the Lexical Approach is that much of the lexicon consists of multi word items of different kinds.... It is a significant improvement to direct learners' attention to larger chunks (since) we store much of our mental lexicon in complete, fully contextualised phrases.

The lexical Approach emphasizes conscious learning for acquisition to occur, that is, encouraging "transition from input to intake through exercises and activities which help the learner observe or notice the L2 more accurately, ensure quicker and more carefully formulated hypotheses about the L2, and so aid acquisition" (Lewis, 1997, p.52). Noticing therefore is prerequisite to internalisation. He goes further to talk about the importance of negative evidence in teaching-learning; this points to the occurrence of potential mistakes in language use, noting that the teacher is an important source of feedback on what is not sanctioned.

Lewis $(1997,2000)$ defines noticing as a teaching strategy in which a teacher draws the learner's attention to the lexical features of the input to which they are exposed. This he argues raises the consciousness of the learner which in turn helps him to turn the input to intake. Although Lewis (2000) notes that noticing is a necessary but not sufficient condition for input to become intake, he argues that if learners are not directed to notice language in a text there exists a danger that they will 'see through the text' and therefore fail to achieve intake. He proposes a sequence of observehypothesize - experiment cycle rather than the erstwhile present-practice-produce paradigm. Ivor and Carlos (2003b.) believe, like Lewis, that encouraging learners to notice language, specifically lexical chunks and collocations, is central to any methodology connected to a lexical view of language. Kryszewska (2003) also points out the importance of 'conscious acquisition' in the language learning process and believes that modelling teaching on the basis of real English, that is corpus of real English, will enhance the communicative power of second language learners.

Noticing is a complex process: it involves the intake both of meaning and form, and it takes time for learners to progress from initial recognition to the point where they can internalize the underlying rule (Batstone, 1996). According to Ivor and Carlos (2003a.), noticing can take a number of forms; guided by the teacher i.e. the teacher directs the students' attention to lexical features thought to be useful; 'self-directed', i.e. the students themselves select features they think will be useful for them; noticing is explicit, e.g. when items in a text are highlighted; implicit e.g. when the 
teacher reformulates a student's text. In all, noticing enables teachers to raise awareness of the language in their learners. According to Tomlinson (2003) and Ivor and Carlos (2003 a.), noticing entails;

1. Paying deliberate attention to features of language in use to help learners notice the gap between their own performance in the target language and the performance of proficient users of the language.

2. Noticing gives salience to a feature, so that it becomes more noticeable in future input, so contributing to the learner's psychological readiness to acquire that feature.

3. The main objective is to help learners to notice for themselves how language is typically used so that they will note the gaps and achieve learning readiness and independence from the teacher and teaching materials.

4. The first procedures are usually experiential rather than analytical and aim to involve the learners in affective interaction with a potentially engaging text. [That is, learners read a text, and respond with their own views and opinions before studying the language in the text or answering comprehension type questions.]

5. Learners are later encouraged to focus on a particular feature of the text, identify instances of the feature, make discoveries and articulate generalizations about its use.'

Beyond the lexical approach, this learning theory has attracted quite a lot of comments. For instance, Cross (2002. p.1) asks if noticing is a valid concept for second language acquisition. He argues that "this notion has gained wide support on the basis of intuition and assumption rather than on the findings of appropriate and exhaustive empirical research". Therefore he suggests practical assessment of it in L2 situations. He examined the assumed interface in second language acquisition and notes that raising the consciousness of learners on language items is preliminary to actual noticing. This term, consciousness raising means the drawing of learners' attention to the formal properties of language. He stresses that "following formal instruction as consciousness raising, learners may then notice a particular linguistic feature in subsequent input and observes that a key difference between noticing and consciousness raising is that noticing has supposed implications for language processing and the actual acquisition of linguistic features. However, not everyone agrees with this distinction. Schmidt (1990) who is one of the earliest proponents of noticing is of the view that attention, consciousness, noticing and awareness are synonymous terms. And we agree. In assessing the validity of this concept, Cross (2002) points to contrasting views on the soundness of the theoretical basis of the method but argues that only empirical research can adequately attest to its usefulness in language learning. But again, he notes that such researches are, at the moment, largely far and between.

Earlier, Schmidt (1990, 1995) discussed the three significant stages in language learning; awareness, intention and knowledge. The first step involves the act of noticing. He explains that what learners notice in input is what becomes intake for learning and asserts that whether noticing is deliberate or purely unintentionally (that is a learner attends to a linguistic form in the input), if language is noticed it becomes intake; and that noticing is a necessary condition for L2 acquisition. According to Schmidt, a number of factors cause noticing in the input. For example, instruction; formal direction of learners attention to language features; frequency, repeated instruction or frequent use of a language items; perceptual salience; prominence or salience of a language item at input; skill level, ability of people to recognize and process previously met language items; task demands; ability of the teacher to structure a teaching in such a way to enable noticing of features necessary to perform the task and comparing; leading the learner to observe the contrasts between the new knowledge and his current interlanguage. This implies a comparison between the observed input and the typical output of the learner and thus focuses on the gap between the two to create insight and eventual intake. Schmidt (1995, pp.27-28 concludes his impression of noticing in the following words;

there is no compelling evidence of any learning without awareness.... I am not so sanguine that noticing hypothesis can either be proved or disproved because subjective awareness is fleeting and cannot be completely recorded (and) it cannot be falsified for the same reason. I would argue that the correlation between information processing and subjective experience is too high to be coincidental.

Lowe $(2003$, pp. 4, 6) with regard to the relevance of noticing points out that traditional models of teaching e.g. classical grammar, transformational grammar, functional grammar and even the process grammars were not designed for language learning. He argues that they were meant only as a way of describing language as a phenomenon and thus "teachers and applied linguists have had to extrapolate language descriptions, over the years, for our own purposes". Although he agrees that each of these models is qualitative and valid, he believes that what we needed was a theoretical base for the second language classroom. This he says, is in recognition that teaching is not learning, and that what is taught is not necessarily what is learnt. But such basis will still allow us to talk about learning and teaching at the same time. He finds this model in "noticing"; as a valid starting point in discussing second language learning. According to him a clear difference between this model and the other older conventional models of teaching is that while the teacher controls teaching, he is no longer in control of learning. Rather, he says, learning is now a cyclical, organic, and invisible process, which the teacher can only marginally influence. Therefore, whatever a teacher does, his sole aim is to assist a learner focus on some aspect of language so that in the process, he may notice it. He concludes that i) noticing is a psychological process which takes time to complete, ii) the teacher can point a learner toward it but cannot definitely make him achieve it and iii) the classroom period is the moment of teaching, not necessarily learning. He however, cautions that we need not throw away the old models because of the new ones; rather we should integrate the new into the old or use the old with new awareness. It becomes evident that this approach relies on education administrators and teachers for implementation. This role of the teacher is discussed in the next section. 


\section{B. The Role of the Teacher}

The teacher is the linchpin of education and is therefore pivotal to learning. As the custodian of knowledge, learners depend on him or her for transfer. He occupies a critical position which determines the nature of knowledge obtained by the students. Whatever he knows or does not know gets transferred. Abutting this point is the statement credited to John Woods in Kotelnicov (2009, p.2) "You can't not communicate. Everything you say or do or don't say and don't do sends a message to others." The teacher is evidently in the eye of the educational storm in the country today.

Because the traditional approaches to teaching have not adequately resulted in successful acquisition of language, contemporary methods of teaching such as noticing has been proposed. It is incumbent on the teacher therefore to incorporate the new insights into his teaching; to expose learners sufficiently to language, direct them to real English by exposing errors in performance. The difficulty which arises here, however, is that the teacher was not himself trained in this mode and in many cases is resistant to change.

Commenting on the need for change of the teachers' mindset, Lewis (1993, p. viii) observes that many a language teacher is antithetical to any change that challenges the established traditions in linguistic description. He warns that the teaching profession cannot rely simply on recipes and challenges teachers to "exhibit sufficient intellectual curiosity and readiness to change which is normally associated with professional status".

Affirming the significant role of the teacher in the learning process, Eyisi (2003, p.103) contends that "the teacher is a beacon, a model, an example and a standard bearer of English usage in our schools. He must possess some degree of expertise and proficiency in the use of English, otherwise he is a veritable generator and perpetrator of errors; he fertilizes errors that are on the verge of extinction".

Williams (2003) has also argued that the most useful role of the teacher is in consciousness-raising, in encouraging noticing on the part of the learners. In other words, the teacher becomes more of a learning manager, giving students strategies to use outside the classroom while at the same time providing exposure to as much appropriate, quality language as possible. The implication, according to Thornbury (1997) is "No noticing, no acquisition."

Although Williams applied 'noticing' to teaching collocational strings, the same method can be successfully applied to teaching other aspects of language use; grammar, pronunciation as well as lexis. What is important is giving the learner sufficient exposure to correct uses of the language. It is in recognition of its value for learning that the present study applies noticing to negative evidence; directing learners to or raising their awareness of the wrong usages to avoid.

It is hoped that this will enable them produce as limpid a communication as possible because repeated errors become confirmed if not corrected and unless the learner is made aware of them he cannot learn from them (Eyisi, 2003). The place of the teacher in effective communication in education is encapsulated in Kotelnikov's contention that the meaning of communication is the response it elicits. This underlines the fact that students' performance is more or less a reflection of the performance of the teacher. The performance of the teacher forms the subject of the following section.

\section{DAta PRESENTATION AND ANALYSIS}

In this section the test sentences administered to the teachers and the results obtained are presented, analysed and inferences drawn. The teachers were exposed to one hundred grammatically wrong usages in English, especially those relating to the language of teaching and of teachers. The aim was to raise their awareness of them, to analyse the errors and to guide them towards internalisation of their correct usages. The research subjects were drawn from eight secondary schools each from Maiduguri and Benin metropolis; five teachers from each. The research subjects were grouped into four; each consisting ten teachers. Each group was exposed to a set of twenty five expressions; five expressions from each of the five groups of errors categorised below. They were asked to assess the sentences for grammaticality by ticking the correct ones and crossing the incorrect ones and then, to indicate the fault by circling the faulty part.

The teachers, eighty in number, worked in groups to enable consultation and the application of wider spectrum of knowledge. The teachers of English constituted a separate group; this was necessary to determine the real value of English as an access subject through the performance rating of its teachers. The errors were systematically classified into five groups, each group consisting twenty expressions; errors in the uses of determiners, nouns, verbs, prepositions and idiomatic expressions. The errors were carefully selected to reflect very common wrong usages that have defied indirect teaching.

It was necessary to also select research objects from two totally different settings so as to 1) rule out the factor of localization of errors and rather zero in on the global issues attending the learning of English in a second language milieu and 2) to achieve good representativeness of the research population. Therefore, teachers were taken from the northern and southern parts of the country for the experimentation. Other characteristics of the test subjects are that they consist of both male and female and were drawn from both private and public schools. It is prudent to mention that a further reason for combining teachers from private and public school, beyond the cross fertilization of ideas, is to establish the content knowledge of the teacher as crucial for teaching irrespective of physical domain. Because these differences did not show significant impact on the general performance of the subjects, analysis of the results was treated unitarily. The first ten expressions in each group are shown below as a sample of the entire data set. 
TABLE 1:

DATA: TEST SENTENCES

\begin{tabular}{|c|c|c|c|c|c|}
\hline $\mathbf{S} / \mathbf{n}$ & $\begin{array}{l}\text { Errors involving } \\
\text { determiners }\end{array}$ & Errors involving nouns & Errors involving verbs & $\begin{array}{l}\text { Errors involving } \\
\text { prepositions }\end{array}$ & $\begin{array}{l}\text { Errors involving } \\
\text { idiomatic expressions } \\
\end{array}$ \\
\hline 1 & $\begin{array}{l}\text { English language is a } \\
\text { very difficult subject. }\end{array}$ & $\begin{array}{l}\text { The whereabout of the } \\
\text { student is still unknown. }\end{array}$ & $\begin{array}{l}\text { Sarah, are you with my } \\
\text { notebook? }\end{array}$ & $\begin{array}{l}\text { He made the comments } \\
\text { to my hearing. }\end{array}$ & $\begin{array}{l}\text { We should go into the } \\
\text { office turn by turn. }\end{array}$ \\
\hline 2 & $\begin{array}{l}\text { Majority of the students } \\
\text { failed the examination. }\end{array}$ & $\begin{array}{l}\text { The students were told to } \\
\text { cut all the grasses around } \\
\text { the classrooms. }\end{array}$ & $\begin{array}{l}\text { The minutes of the last } \\
\text { meeting was read by the } \\
\text { secretary. }\end{array}$ & $\begin{array}{l}\text { The teacher gave us a } \\
\text { test on mathematics. }\end{array}$ & $\begin{array}{l}\text { Lady and gentlemen, I } \\
\text { have come to the end } \\
\text { of my speech. }\end{array}$ \\
\hline 3 & $\begin{array}{l}\text { That your sister is very } \\
\text { intelligent. }\end{array}$ & $\begin{array}{l}\text { Heads of department are } \\
\text { in a meeting. }\end{array}$ & $\begin{array}{l}\text { Prof. Iyamu was the } \\
\text { former head of } \\
\text { academics. }\end{array}$ & $\begin{array}{l}\text { You should not write } \\
\text { anything on the margin. }\end{array}$ & $\begin{array}{l}\text { My house is a stone } \\
\text { throw from here. }\end{array}$ \\
\hline 4 & $\begin{array}{l}\text { I attended university of } \\
\text { Benin. }\end{array}$ & $\begin{array}{l}\text { The way and manner the } \\
\text { report was given is } \\
\text { suspect. }\end{array}$ & $\begin{array}{l}\text { Hauwa got a grade B in } \\
\text { English, she tried. }\end{array}$ & $\begin{array}{l}\text { We condoled them on } \\
\text { the death of their } \\
\text { mother. }\end{array}$ & $\begin{array}{l}\text { There are kings and } \\
\text { there are kings. }\end{array}$ \\
\hline 5 & $\begin{array}{l}\text { The principal is fond of } \\
\text { accepting bribe. }\end{array}$ & $\begin{array}{l}\text { The deep freezer in the } \\
\text { dinning hall is very big. }\end{array}$ & $\begin{array}{l}\text { The headmaster } \\
\text { requested for the boy's } \\
\text { result. }\end{array}$ & $\begin{array}{l}\text { Musa and Mairo are in } \\
\text { good terms with each } \\
\text { other. }\end{array}$ & $\begin{array}{l}\text { I know fully well that } \\
\text { she loves me. }\end{array}$ \\
\hline 6 & $\begin{array}{l}\text { The Nigerian society } \\
\text { prizes men more highly } \\
\text { than women. }\end{array}$ & $\begin{array}{l}\text { Mary is an alumnus of } \\
\text { this institution. }\end{array}$ & $\begin{array}{l}\text { I was beaten by the rain } \\
\text { on my way to school. }\end{array}$ & $\begin{array}{l}\text { I came to you with the } \\
\text { belief that you'll help } \\
\text { me. }\end{array}$ & $\begin{array}{l}\text { A beggar has no } \\
\text { choice. }\end{array}$ \\
\hline 7 & $\begin{array}{l}\text { Gaza town is in } \\
\text { shambles. }\end{array}$ & $\begin{array}{l}\text { Mr. Sule, I have a good } \\
\text { news for you. }\end{array}$ & $\begin{array}{l}\text { How much did you buy } \\
\text { those beautiful shoes? }\end{array}$ & $\begin{array}{l}\text { Please sleep over the } \\
\text { issue and give me your } \\
\text { reply tomorrow. }\end{array}$ & $\begin{array}{l}\text { Don't worry, with time } \\
\text { they will face the } \\
\text { music. }\end{array}$ \\
\hline 8 & $\begin{array}{l}\text { John is our most trusted } \\
\text { staff }\end{array}$ & $\begin{array}{l}\text { I saw the teacher at the } \\
\text { airport, he had so many } \\
\text { luggages. }\end{array}$ & $\begin{array}{l}\text { Ade, your uniform is } \\
\text { torn, tell your father to } \\
\text { sew a new one for you. }\end{array}$ & $\begin{array}{l}\text { On the long run the man } \\
\text { died of heart attack. }\end{array}$ & $\begin{array}{l}\text { The taste of the } \\
\text { pudding is in the } \\
\text { eating. }\end{array}$ \\
\hline 9 & That child has cough. & $\begin{array}{l}\text { My mother is an } \\
\text { academician in university } \\
\text { of Maiduguri. }\end{array}$ & $\begin{array}{l}\text { The prefect raised up the } \\
\text { key and asked, who has } \\
\text { this key? }\end{array}$ & $\begin{array}{l}\text { The vendor supplies us } \\
\text { newspapers daily. }\end{array}$ & $\begin{array}{l}\text { I completed the } \\
\text { assignment in the } \\
\text { twinkle of an eye. }\end{array}$ \\
\hline 10 & $\begin{array}{l}\text { My son got admission } \\
\text { to the faculty of Arts. }\end{array}$ & $\begin{array}{l}\text { The use of slangs is } \\
\text { prohibited in this school. }\end{array}$ & $\begin{array}{l}\text { Miriam, are you with my } \\
\text { notebook? }\end{array}$ & $\begin{array}{l}\text { Who did you give the } \\
\text { book? }\end{array}$ & $\begin{array}{l}\text { Birds of the same } \\
\text { feather flock together. }\end{array}$ \\
\hline
\end{tabular}

\section{DISCUSSION OF RESULTS}

The results of the language assessment test administered to the research subjects are presented in the Table below.

TABLE 2:

TEST RESULTS

\begin{tabular}{|l|l|l|l|l|l|}
\hline PERFORMANCE & $\begin{array}{l}\text { GROUP } \\
\text { A }\end{array}$ & $\begin{array}{l}\text { GROUP } \\
\text { B }\end{array}$ & $\begin{array}{l}\text { GROUP } \\
\text { C }\end{array}$ & $\begin{array}{l}\text { GROUP } \\
\text { D }\end{array}$ & TOTAL \\
\hline Number of sentences marked correct & 19 & 15 & 14 & 15 & 63 \\
\hline Number of sentences marked wrong & 6 & 10 & 11 & 10 & 37 \\
\hline Percentage performance & $24 \%$ & $40 \%$ & $44 \%$ & $40 \%$ & $37 \%$ \\
\hline
\end{tabular}

The Table shows the percentage passes of the groups (A - D) as $24,40,44$, and 40 respectively. These scores represent the number of sentences $(6,10,11,10)$ they were able to identify as wrong out of the twenty five wrong sentences presented to them. The performance rating for each group as shown in the Table fell below 50\%; whereas the average percentage came to $37 \%$. Obviously, in all cases, the teachers found more 'correct' expressions than incorrect ones. Group B is the English teachers group; their performance is identical to that of group D, and lower than that of group $\mathrm{C}$ although marginally.

The implication of these findings are of grave consequences; all the teachers, including those trained to teach English, exhibited less than 50\% proficiency in English. This level of mastery of English; 37\% on the average, is obviously too low for teachers in the 21 st century. This calls for worry especially because those entrusted to teach the subject seem not to be better the others. And where the teachers themselves are unable to recognize errors they become the very organs of their propagation in our school system.

\section{CONCLUSION}

The finding of this research corroborates the existence of a gap between input and the metalanguage of the L2 user of any language and shows that noticing this gap is a possible way of bridging it. It demonstrates therefore that drawing the attention of a language user especially to those properties of language wrongly perceived by the user causes him to be aware of them and may enable him in the long run to learn correct uses of them. It must be pointed out that this study has experimented only with one aspect of noticing and therefore cannot claim that noticing the gap or negative evidence alone is adequate for input to become intake. Rather, it recognizes that internalisation of language is a process which calls for both time and effort on the part of learner and teacher and as such, at best, we can say that raising the awareness of these selected teachers is, for them, just a step toward learning. 
As pointed out earlier, noticing gives the teacher control over teaching and not learning while the teaching time is exclusively for teaching and not necessarily for learning. Although learning may occur, the teacher's primary objective is to guide the learner toward it. What do we say then? Noticing puts the pressure of learning off the teacher yet we say that the teacher remains nonetheless accountable because his teaching must be not only structured but properly goal directed. This calls for development and creativity on the part of the teacher.

Therefore the need to shift focus from students to teachers themselves is pertinent. This is validated by the Federal Government's initiative in its millennium goals, to retrain primary teachers in the country; an initiative which should be extended to secondary school teachers as well. The teacher must position himself to model the language of classroom communication no matter his discipline in order to enable the transference and accessibility of the knowledge which he possesses and in turn has intended to pass onto his students. It is only when that which was intended reaches those it was intended for that meaningful communication can be said to have taken place. To attain this position demands from the teacher, among other things, the zeal for self development, professional curiosity and the readiness to change both in mindset and method.

The study has brought to the fore the value of noticing in second language acquisition. It now behoves the teacher to take due advantage of this method if only for the sake of intellectual curiosity; by exposing his students to correct usages in English and wrong usages to avoid. This is in recognition of the role of the teacher as the provider of positive feedback to the students. It is our submission that noticing, raising the consciousness of learners on what is right or wrong usage is profitable for learning.

However, wider research into the validity of this method is still advocated before its total adoption in schools and incorporation into approved teaching materials in Nigeria. For example, all aspects of noticing should be experimented over long periods of time in the classroom to ascertain their correlation to learning. It seems prudent to reiterate these identified influences on noticing which we propose for further experimentation. There are instruction; formal direction of learners attention to language features, frequency; repeated instruction or frequent use of language items, perceptual salience; prominence or salience of a language item at input, skill level; ability of people to recognize and process previously met language items, task demands; ability of the teacher to structure a teaching in such a way to enable noticing of features necessary to perform the task and comparing; leading the learner to observe the contrasts between the new knowledge and his current interlanguage (Schmidt, 1990, 1995). When these steps are duly followed in language teaching, it may indeed become easier for learning to occur because only then will input turn out to be intake.

\section{REFERENCES}

[1] Batstone, R. (1996). Key Concepts in ELT: Noticing. ELT Journal 50 (3) 273-273.

[2] Cross, J. (2002). Noticing in SLA: is it a valid concept? TESL-EJ Teaching English as a second or foreign language, vol. 6, no.3.

[3] Eyisi, J. (2003). Common Errors in the use of English 2ed. Onitsha: Africana First Publishers.

[4] Ivor, T. Carlos. I. (2003b.). Lexical approach 2 - What does the lexical approach look like. $\mathrm{http} / / /$ www.teachingenglish.org.uk/articles/lexical-approach-2-what-does-lexical-approach-look Accessed 02/09/2009.

[5] Ivor T. and Carlos, I. (2003a.). Lexical approach 1 - What does the lexical approach look like. http://www.teachingenglish.org.uk/articles/lexical-approach-1-what-does-lexical-approach-look Accessed 04/09/2009.

[6] Kotelnikov, V. (2009). How to Communicate Effectively Your Ideas to Others.

[7] Kryszewska, H. (2003). Why I won't say goodbye to the lexical approach. In Humanising language teaching, 5 (2) 1-11.

[8] Lewis, M. (1993). The Lexical Approach, Hove: Language Teaching Publications.

[9] Lewis, M. (1997). Implementing the Lexical Approach: Putting Theory into Practice. Hove: Language Teaching Publications.

[10] Lewis, M. (2000). Language in the lexical approach. In Teaching Collocation: Further Developments. In The Lexical Approach, Michael Lewis (ed.), 126-154.Hove: Language Teaching Publications.

[11] Lowe, C. (2003) Noticing: a re-appraisal of its implications for methodology. www.ihworld.com/ihjournal/articles/04NOTICING. Accessed 13/10/2009.

[12] Schmidt, R. (1990). The role of consciousness in second language learning. Applied Linguistics 11, 129-158.

[13] Schmidt, R. (1995). Consciousness and foreign language learning: A tutorial on the role of attention and awareness. In R. Schmidt (Ed.), Attention and awareness in foreign language teaching and learning (Technical Report No. 9) (pp. 1-64). Honolulu: University of Hawai'i at Manoa.

[14] Thornbury, S. (1997). Reformulation and reconstruction: tasks that promote 'noticing'. ELT Journal 51(4): 326-334.

[15] Tomlinson, B et al (2003). Ten Questions about Language Awareness. ELT Journal 57(3) 251-259.

[16] Williams, B. (2003). Collocation with advanced learners 1 - Not entirely ... proper/ appropriate/ good. BBC Teaching English www.TeachingEnglish.org.uk/think/article. Accessed 10/12/2009. 


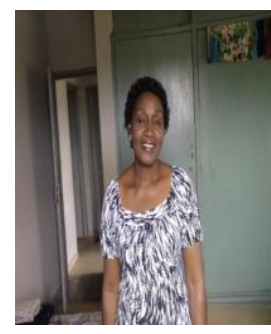

Alexandra Uzoaku Esimaje was born in Oguta, Nigeria, in August, 1962. Esimaje was formally educated in the country and obtained a first school leaving certificate from Shell Camp Primary School, Owerri, in 1972, a West African School Leaving Certificate from Owerri Girls Secondary School in 1979, a Bachelor of Arts Degree (B.A. English) from University of Ilorin in 1984, a Master of Arts Degree (M.A. English) from University of Maiduguri in 2000, and in University of Maiduguri, has just completed a Doctor of Philosophy Degree (P. h D. English).

She has worked as teacher and lecturer in various institutions of learning for a period of over twenty years. Presently, she lectures English in Benson Idahosa University, Benin City, Nigeria, where she was the Head of the English Department and has also held several other positions. She is widely published nationally and has Lecaps Publishers, (2002). some foreign publications to her credit. She has authored one book titled Oral English and Grammar. Jos:

Dr. (Mrs.) Esimaje is a member of many professional bodies such as Nigeria English Studies Association (NESA), English Language Teaching Today (ELTT) and Nigeria Association for Semiotics Studies (NASS). She holds the fellowship of the American Council of Learned Societies (F.ACLS) having won the 2010 African Humanities Programme award. She has also worked for the British Council as instructor in a year-long national workshop for training teachers of English in Nigeria. For four years now, she has been involved in a similar project by the Nigerian Government to re-train teachers of English in Primary Schools. 